\title{
PENGEMBANGAN MODUL INFORMASI KARIR UNTUK PESERTA DIDIK KELAS X JURUSAN TEKNIK KENDARAAN RINGAN (TKR) SMK NEGERI 26 JAKARTA
}

\author{
Praditya Rizky Hutama ${ }^{1}$ \\ Dra. Indira Chanum, M.Psi. ${ }^{2}$ \\ Herdi, M.Pd. ${ }^{3}$
}

\begin{abstract}
Abstrak
Penelitian ini dilakukan dengan permasalahan utama, yaitu kurangnya sumber yang dapat digunakan guru BK dalam memberikan layanan Bimbingan dan Konseling (BK) karir. Tujuan penelitian ini adalah untuk menghasilkan bahan ajar berupa Modul Informasi Karir Untuk Peserta Didik Kelas X Jurusan Teknik Kendaraan Ringan (TKR) SMK Negeri 26 Jakarta yang diharapkan dapat membantu peserta didik mencapai kematangan karir. Metode yang digunakan dalam penelitian ini adalah Research and Development $(R \& D)$ dengan melalui 5 dari 10 tahapan penelitian yang Borg \& Gall yang di modifikasi oleh Sugiyono. Peneliti melakukan pengumpulan data analisis kebutuhan dengan beberapa teknik, yaitu wawancara dan angket. Kompetensi-kompetensi yang terdapat dalam modul dikembangkan dari hasil analisis kebutuhan (mengacu kepada teoriteori mengenai informasi karir). Uji validasi pada penelitian ini dilakukan oleh 3 validator, yaitu ahli media, ahli materi, dan guru BK. Peneliti juga melakukan pengujian keterbacaan pada subjek calon pengguna produk hasil pengembangan yaitu peserta didik kelas Xjurusan TKR dengan responden sebanyak 8 orang. Dengan demikian, simpulan dari hasil penelitian ini adalah bahwa modul informasi karir yang dikembangkan dapat digunakan oleh guru BK dalam memberikan layanan bimbingan karir di sekolah.
\end{abstract}

Kata kunci: Modul, Informasi Karir, Kematangan Karir

\section{Pendahuluan}

Sekolah menengah kejuruan (SMK) sebagai bentuk satuan pendidikan kejuruan sebagaimana ditegaskan dalam penjelasan pasal 15 UU SISDIKNAS, merupakan pendidikan menengah yang mempersiapkan peserta didik terutama untuk bekerja dalam bidang tertentu.

Menurut Laporan Bulanan Data Sosial Ekonomi edisi Februari 2014 yang di keluarkan secara resmi oleh Badan Pusat Statistik (BPS), angka Tingkat Pengangguran Terbuka (TPT) menurut pendidikan yang ditamatkan per Agustus 2013 ialah sebagai berikut, dengan presentase tertinggi yaitu SMK (11.19\%), kemudian disusul dengan SMA (9.74\%), SMP (7.60\%), Diploma I/II/III (6.01\%), Universitas/Sarjana (5.50\%), SD ke bawah (3.51\%).

\footnotetext{
1 Mahasiswa Jurusan Bimbingan dan Konseling FIP UNJ, pradityarh@gmail.com

2 Dosen Bimbingan dan Konseling FIP UNJ, indirasunito@yahoo.com

3 Dosen Bimbingan dan Konseling FIP UNJ, herdiunj5@gmail.com
} 
Tingginya angka pengangguran terdidik terutama pada lulusan SMK menunjukkan bahwa belum tercapainya tujuan khusus pendidikan menengah kejuruan seperti yang tertera dalam Undang-Undang No. 20 Tahun 2003 tentang Sistem Pendidikan Nasional yaitu Pendidikan kejuruan merupakan pendidikan menengah yang mempersiapkan peserta didik terutama untuk bekerja dalam bidang tertentu.

Mengacu pada teori life span career Super (Sharf, 1992), idealnya individu (peserta didik) yang berada di jenjang SLTA baik SMA/SMK (15 - 24 tahun) berada pada tahap eksplorasi (exploration) yaitu proses yang terjadi pada remaja dalam mengembangkan minat, kemampuan, nilai-nilai dan kemudian memasuki masa transisi, yang mana seluruh unsur tersebut sangat berperan dalam kematangan karir seseorang (remaja). Dalam tahap eksplorasi ini peran seorang guru BK di sekolah ialah sebagai fasilitator dalam membantu pengembangan diri peserta didik dan memberikan informasi karir yang dibutuhkan oleh peserta didik untuk mencapai kematangan karirnya. Salah satu metode pemberian layanan informasi yang dapat digunakan adalah penggunaan modul.

Hasil kajian teoretik maupun empirik dapat disimpulkan bahwa tingginya angka pengangguran terdidik dari SMK bisa dicegah sedini mungkin dengan pemberian layanan informasi karir yang optimal dari guru BK di sekolah. Layanan informasi karir tersebut dapat dilakukan dengan berbagai macam metode layanan, salah satunya ialah dengan menggunakan media pembelajaran berupa modul atau bahan ajar cetak.

Berdasarkan kajian teoretik dan fakta empirik tersebut, penelitian ini difokuskan pada pengembangan modul informasi karir untuk peserta didik kelas X jurusan Teknik Kendaraan Ringan (TKR) di SMK Negeri 26 Jakarta.

\section{Kajian Teoritik \\ Informasi Karir}

Dewa Ketut Sukardi (2010:116-117) mengemukakan, pada da-sarnya informasi karir terdiri dari fakta-fakta mengenai pekerjaan, jabatan, atau karir, dan bertujuan untuk membantu individu memperoleh pandangan, pengertian, dan pema- haman tentang dunia kerja dan aspek-aspek dunia kerja. Lebih lanjut, dijelaskan bahwa informasi karir/jabatan meliputi beberapa hal berikut: (1) Potensi pekerjaan, termasuk luasnya, komposisinya, faktor- faktor geografis, jenis kelamin, tingkat usia, dan besarnya kelompok industri, (2) Struktur kerja dan besarnya kelompok-kelompok kerja, (3) Ruang ling-kup dunia kerja, meliputi pemahaman lapangan kerja, perubahan populasi permintaan dari masyarakat umum yang membaik, dan perubahan teknologi, (4) Perundang-undangan peraturan atau perjanjian kerja, (5)Sumber-sumber informasi dalam rangka mengadakan studi berkait-an dengan pekerjaan, (6) Klasifikasi pekerjaan dan informasi pekerjaan, (7) Pentingnya dan kritisnya pekerjaan, (8) Tugastugas nyata dari pekerjaan dan hakikat dari pekerjaan, (9) Kualifikasi yang memaksa untuk bekerja dalam bermacam-macam pekerjaan, (10) Pemenuhan kebutuhan untuk bermacam-macam pekerjaan, (11) Metode dalam memasuki pekerjaan dan meningkatkan prestasi kerja, (12) Pendapatan dan bentukbentuk imbalan dari bermacam-macam pekerjaan, (13) Kondisi-kondisi kerja dalam berjenis-jenis pekerjaan, (14) Kriteria untuk penilaian terhadap materi informasi pekerjaan (15) Ciri-ciri khas tempat kerja.

Pendapat lain yang mengemukakan mengenai informasi karir yaitu Donald Edwin Super. Menurut Super (1992: 158) informasi karir terdiri atas dua komponen dasar, yaitu: (1) berhubungan dengan tugas perkembangan ketika individu harus mengetahui minat dan kemampuan dirinya, mengetahui cara orang lain mempelajari hal-hal yang berhubungan dengan pekerjaannya, dan mengetahui alasan orang lain berganti pekerjaan; (2) konsep yang berkaitan dengan pengetahuan tentang tugas-tugas pekerjaan dalam satu vokasional dan perilaku-perilaku dalam bekerja. Donald Edwin Super meyakini bahwa sangat penting bagi individu untuk memiliki pengetahuan tentang dunia kerja sebelum dilakukan konseling.

Berdasarkan kedua pendapat diatas dapat disimpulkan bahwa dalam memberikan layanan informasi karir, guru BK tidak hanya memberikan pengetahuan yang berkaitan dengan dunia karir atau suatu jabatan saja, akan tetapi, guru BK juga harus membantu peserta didik mengenali karakteris- 
tik diri dan potensi- potensi yang dimilikinya agar kelak peserta didik dapat memilih karir atau suatu jabatan tertentu yang sesuai dengan preferensi yang ada pada dirinya.

\section{Modul}

Media pembelajaran bisa juga meliputi alat dan bahan itu sendiri. Sebagai contoh, media video meliputi bahan video pembelajaran dalam format VCD atau DVD, di samping itu juga meliputi alatnya yaitu VCD/DVD player. Sementara itu, untuk media cetak seperti modul bisa berdiri sendiri, atau dapat diintegrasikan dengan media pembelajaran lainnya, seperti media audio atau video.

Menurut Mulyasa (2008: 43) modul adalah media yang digunakan dalam suatu proses pembelajaran mengenai suatu satuan bahasan tertentu yang disusun secara sistematis operasional, dan terarah untuk digunakan oleh peserta didik, disertai dengan pedoman penggunaannya untuk para guru. Sebuah modul adalah pernyataan suatu pembelajaran dengan tujuan-tujuan, pretes aktivitas belajar yang memungkinkan peserta ddik memperoleh kompetensikompetensi yang belum dikuasai dari hasil pretes, dan mengevaluasi kompetesinya untuk mengukur keberhasilan belajar.

Tujuan utama sistem pembelajaran menggunakan modul adalah untuk meningkatkan efisiensi dan efektivitas pembelajaran di sekolah, baik waktu, dana, fasilitas, maupun tenaga guna mencapai tujuan secara optimal.

Berdasarkan Peraturan Lembaga Administrasi Negara No. 5 Tahun 2009 tentang Pedoman Penulisan Modul Pendidikan dan Pelatihan disebutkan bahwa ciri-ciri sebuah modul yang baik disusun sesuai dengan kebutuhan belajar dalam sebuah proses pembelajaran, ciri-ciri tersebut ialah: (1) Dapat dipelajari oleh peserta secara mandiri, tanpa bantuan atau seminimum mungkin bantuan dari instruktur (self instructional), (2) Mencakup deskripsi dan tujuan kegiatan, batasan-batasan, standar kompetensi yang harus dicapai, kompetensi dasar, indikator keberhasilan peserta didik, metode, rangkuman, latihan-latihan, yang secara keseluruhan ditulis dan dikemas dalam satu kesatuan yang utuh (self contained), (3) Dapat dipelajari secara tuntas, tidak tergantung pada media lain atau tidak harus digu- nakan bersama-sama dengan media lain (independent), (4) Memuat alat evaluasi pembelajaran untuk mengukur tingkat kecakapan peserta terhadap modul (self assessed), (5) Memiliki sistematika penyusunan yang mudah dipahami dengan bahasa yang mudah dan lugas, sehingga dapat dipergunakan sesuai dengan tingkat pengetahuan peserta didik (user friendly).

\section{Metodologi Penelitian}

Penenelitian dilaksanakan di Sekolah Menengah Kejuruan (SMK) Negeri 26 Jakarta. Pemilihan tempat penelitian berdasarkan pada rekomendasi dosen pembimbing serta pertimbangan waktu dan lokasi. Waktu pelaksanaan penelitian dilaksanakan pada bulan Mei 2014 sampai dengan bulan Desember 2014. Pada penelitin ini, digunakan metode penelitian dan pengembangan atau dalam bahasa inggrisnya disebut Research and Development (R\&D). Borg dan Gall mengemukakan pendapat yang tidak jauh berbeda mengenai penelitian R\&D yaitu

'Educational research and development $(R \& D)$ process is used to develop and validate educational products' (Penelitian pengembangan dalam pendidika merupakan suatu proses yang digunakan untuk mengembangkan dan memvalidasi produk pendidikan).

Sugiyono memodifikasi pendekatan penelitian pengembangan Borg \& Gall dengan tetap mempertahankan 10 tahapan yang ada, akan tetapi peneliti hanya melakukan penelitian sampai tahap kelima saja, hal ini dikarenaka pertimbangan waktu dan biaya. Berikut adalah langkah- langkah penelitian (1) identifikasi masalah, (2) pengumpulan informasi, (3) desain produk, (4) validasi desain, dan (5) perbaikan desain.

Setelah mengetahui permasalahan yang terjadi di lapangan, peneliti melakukan pengumpulan data yang dilakukan untuk mengetahui tingkat kebutuhan peserta didik terhadap modul yang akan dikembangkan. Instrumen (analisis kebutuhan/need assessment) dikembangkan berdasarkan teori informasi karir yang mencakup pengetahuan tentang dunia kerja atau jabatan serta menggali potensi-potensi peserta didik.

Dalam penelitian pengembangan modul infor- 
masi karir ini, peneliti melakukan pungumpulan data dengan cara memberikan angket penilaian kepada validator (uji ahli) serta melakukan uji coba keterbacaan untuk mendapatkan masukan dari calon pengguna modul (peserta didik kelas X jurusan TKR dan guru BK) guna memperbaiki kualitas modul yang dikembangkan.

Teknik analisis data yang digunakan dalam uji validasi ahli adalah teknik evaluasi formatif. Evaluasi formatif adalah proses yang dimaksud untuk mengumpulkan data tentang efektifitas dan efisiensi bahan-bahan pembelajaran berupa kelayakan aspek materi, kelayakan aspek bahasa, kelayakan aspek penyajian, kelayakan efek media terhadap strategi pembelajaran, dan aspek tampilan menyeluruh.

Peneliti menggunakan skala 1-4 untuk menilai kualitas produk dengan kategori 1 untuk sangat kurang, 2 untuk kurang, 3 untuk baik dan 4 untuk sangat baik. Penghitungan pada evaluasi formatif dilakukan dengan menggunakan statistik sederhana. Data yang telah terkumpul dari responden diolah untuk mendapatkan nilai rata-rata.

Langkah selanjutnya adalah menghitung skor untuk menentukan hasil rating, yaitu dengan melakukan penjumlahan jawaban ahli, serta menentukan hasil rating dengan rumus:

$$
H R=\frac{\sum \text { skor uji ahli }}{\sum \text { skor ideal }} \times 100 \%
$$

Selanjutnya, setelah didapatkan hasil rating maka untuk menentukan kelayakan bahan ajar modul dilakukan penilaian berdasarkan skala persentase penilaian sebagai berikut:

Tabel 1

Tabel Skala Persentase Penilaian

\begin{tabular}{|c|c|}
\hline Persentase & Penilaian \\
\hline $81-100 \%$ & Sangat Layak \\
\hline $61-80 \%$ & Layak \\
\hline $41-60 \%$ & Cukup Layak \\
\hline $21-40 \%$ & Kurang Layak \\
\hline $0-20 \%$ & Tidak Layak \\
\hline
\end{tabular}

\section{Hasil Penelitian}

Berdasarkan hasil analisis kebutuhan, dapat disimpulkan bahwa masih banyak peserta didik yang sangat membutuhkan informasi karir, baik itu tentang penggalian potensi diri maupun pengetahuan mengenai dunia kerja atau jabatan. Serta, media cetak merupakan salah satu sumber yang paling mendasar yang dijadikan sebagai sumber informasi mengenai karir. Kemudian hasil dari analisis kebutuhan dikembangkan mejadi desain produk yang setelah itu diuji validasi oleh ahli yang terdiri dari ahli materi, ahli media dan guru BK/konselor.

Uji validasi yang dilakukan kepada ahli materi di bidang bimbingan dan konseling karir (dosen jurusan Bimbingan dan Konseling FIP UNJ) dilakukan untuk melihat kelayakan isi modul yang dikembangkan. Dari hasil uji validasi, diperoleh skor rata-rata 87,85, yang berarti secara keseluruhan modul informasi karir yang dikembangkan berada pada kategori sangat layak.

Secara umum, ahli materi memberikan komentar bahwa modul pembelajaran perlu ditambahkan petunjuk penggunaan. Kesimpulan hasil validasi oleh ahli media adalah Modul pembelajaran ini dinyatakan layak diujicobakan di lapangan dengan revisi.

Uji validasi yang dilakukan kepada ahli media (dosen jurusan Kurikulum dan Teknologi Pendidikan FIP UNJ) dilakukan untuk melihat kelayakan modul yang dikembangkan dari aspek kegrafikan. Dari hasil uji validasi, diperoleh skor rata-rata 65,95 , yang berarti secara keseluruhan modul informasi karir yang dikembangkan berada pada kategori layak.

Secara umum, ahli media memberikan komentar bahwa modul ini masih perlu diperbaiki pada aspek struktur modul, sampul/cover, layout serta penggunaan ilustrasi yang dapat menunjang keefektifan penyamaian informasi. Kesimpulan hasil validasi oleh ahli media adalah modul pembelajaran ini dinyatakan layak diujicobakan di lapangan dengan revisi.

Kemudian, hasil dari uji validasi yang dilakukan kepada guru BK SMK Negeri 26 Jakarta, diperoleh skor rata-rata 95,625, yang berarti secara keseluruhan modul informasi karir yang dikembangkan berada pada kategori sangat layak. 
Secara umum guru BK memberikan komentar yaitu modul informasi karir untuk kelas X jurusan Teknik Kendaraan Ringan ini sudah sesuai dengan kebutuhan lapangan (sekolah dan peserta didik).

Hasil uji validasi ahli materi dan ahli media serta guru BK terhadap modul informasi karir menunjukkan bahwa desain modul yang dirancang dinyatakan layak untuk diujicobakan di lapangan (SMK Negeri 26 Jakarta).

Hasil uji keterbacaan modul informasi karir, adalah dari 8 peserta didik yang terdiri dari masingmasing 4 orang peserta didik kelas X jurusan Teknik Kendaraan Ringan (TKR) 1 dan TKR 2 dihasilkan rata-rata 77,06 yang mana, rerata tersebut termasuk kedalam kategori layak.

Sedangkan kesimpulan dari hasil uji keterbacaan yang dilakukan menunjukkan beberapa hal sebagai berikut: 1) peserta didik memberikan saran agar lebih diperbanyak gambar pada modul agar tampilan modul menjadi semakin menarik sehingga pengguna semakin tertarik untuk mempelajari isi modul atau materi; 2) modul informasi karir dapat diterapkan di SMKN 26 Jakarta; 3) modul yang disusun dapat memberikan referensi tambahan kepada guru BK dalam memberikan layanan informasi di bidang bimbingan karir kepada peserta didik yang berada di kelas X khususnya jurusan TKR.

\section{Simpulan dan Saran}

Berdasarkan hasil penelitian dan pembahasan, dapat ditarik kesimpulan, yaitu:

1. Modul informasi karir yang dikembangkan layak digunakan guru BK/konselor di sekolah.

2. Modul informasi karir yang dikembangkan dapat dimanfaatkan oleh guru BK/konselor dalam upaya memberikan layanan BK karir yang optimal sehingga peserta didik dapat mencapai kematangan karir.

Saran dalam penelitian ini berkenaan dengan pemanfaatan Modul Informasi Karir untuk peserta didik SMK Kelas X Jurusan Teknik Kendara- an Ringan (TKR) dan untuk penelitian selanjutnya yang terkait dengan pengembangan, antara lain:

\section{Untuk Peserta Didik}

Peserta didik diharapkan dapat pelajari informasi karir dengan baik melalui modul informasi karir ini dan terus mencari sumber informasi karir melalui media lain secara aktif.

\section{Untuk Guru BK}

Agar modul informasi karir ini dapat efektif diharapkan penggunaanya tepat sasaran. Guru BK menggunakan modul informasi karir ini dalam memberikan layanan BK karir.

\section{Untuk Peneliti Selanjutnya}

Jika ingin melakukan pengembangan bahan ajar modul informasi karir, diharapkan peneliti berikutnya dapat menguji kembali keefektifan modul ini dan mengembangkan materi-materi yang terdapat di modul ini agar bisa dipergunakan oleh peserta didik dari jurusan selain jurusan Teknik Kendaraan Ringan (TKR).

\section{Daftar Pustaka}

Arikunto, Suharsimi. Manajemen Penelitian. Jakarta: Rineka Cipta. 2010.

Kurniawati, Ika. Modul Pelatihan: Pengembangan Bahan Belajar. Kementerian Pendidikan dan Kebudayaan.

Mulyasa, Enco. Kurikulum Berbasis Kompetensi: Konsep, Karakteristik, dan Implementasi. Bandung: PT Remaja Rosdakarya. 2008.

Riduwan, dkk. Rumus dan Data dalam Analisis Statistika. Bandung: Alfabeta. 2009.

Salahudin, Anas. Bimbingan dan Konseling. Bandung: Pustaka Setia. 2010.

Sharf, Richard S. Applying Career Development Theory to Counseling. California: Brooks/Cole Publishing Company. 1992.

Sugiyono. Metode Penelitian Administrasi: Dilengkapi dengan Metode R\&D. Bandung: Alfabeta. 2010.

Tripina. Skripsi: Pengembangan Buku Teks Bidang Bimbingan Sosial Berbasis Masalah Untuk Meningkatkan kemampuan Siswa Mengatasi Masalah Konflik Interpersonal. Universitas Negeri Jakarta. 2014. 